\title{
TEMPLE BAR: INDEX OF VICTORIAN MIDDLE-CLASS THOUGHT
}

\author{
BY VINCENT C. DE BAUN
}

THE AUTHOR of this interesting study of a Victorian literary periodical received his $M . A$. degree from Rutgers in 1950 and is now completing his work for the doctorate in the field of nineteenth century English literature while serving as a graduate assistant in the Rutgers English Department.

7 OUR generation the middle years of the Victorian era seem somehow infinitely far away, and we are apt to envision that time in mingled impressions of mutton-chop whiskers, crinoline, huge family dinners, prim maidens rendering a musical version of "Come into the Garden, Maud," and Little Nell expiring in a nimbus while manly readers wept. Queen Victoria herself, of course, stands solidly at the center of this montage, as Lytton Strachey described her, "very short, rather stout, quite plain," dressed in mourning and looking pinch-lipped and subtly selfsatisfied. Unfortunately, our generation is the legatee of just this sort of notion of the Victorian age because we are still responding to the rebellion of Strachey and his contemporaries against what they felt to be the stuffiness, hypocrisy, and cant of the middle and late nineteenth century. In recent years, however, as most literary observers have noted, the pendulum of general social and critical opinion has begun to swing in the opposite direction, and a sympathetic understanding, if not a vindication, of that now seemingly distant era is well under way.

Students at Rutgers University who are especially interested in the interaction of Victorian social temper and literary taste are fortunate to have at hand an almost complete set of the English monthly magazine Temple Bar (1860-1906). One hundred thirtyfour volumes of this periodical were issued; the University Library lacks only eight of this total, although scattered groups of pages will also be found missing at rare intervals among the remainder. ${ }^{1}$ Encompassing during its span one of the most industrious and changeful periods in English history, Temple Bar reflected to a

\footnotetext{
1 The missing volumes are 2, 3, 4, 5 (April, I861-July, I862);84 (Sept.-Dec., 1888), roo (index, 1894), 133 and 134 (May-Dec., 1906).
} 
great extent the problems and aspirations which occupied the thoughts of the educated British middle-class. In its pages the present-day reader may find articles on such diverse subjects as railway improvements, the treatment of lunatics, travels down the Avon, the dangers of coal-mining, art criticism, and reviews of popular books of the day that have long since passed into obscurity, plus a good many exhortations to moral and genteel behavior. These were mixed with a scattering of short stories and a good many lachrymose poems about lost loves and dead babies. But the staple fare consisted of serial novels, most of which ran on for twelve or fourteen months. None of these efforts, non-fiction or fiction, could be deemed literature of high seriousness, although they were grave and sober in their treatment of moral problems; but almost always they consciously bespoke the attitudes and aspirations of the vast middleclass that was rising to dominate the essential temper of the greatest nation of its time-solemn, church-going, circumspect, and apparently quite unaware of the paradox of its tearful sentimentality and its intense practicality.

Admittedly an imitation of the highly successful Cornhill Magazine, Temple Bar was the brain-child of John Maxwell, who was eventually to become one of England's most prosperous publishers. The first editor of the new magazine was George Augustus Sala, who enjoyed a growing reputation as a reporter for the Daily Telegraph and had been a close associate of Thackeray on the Cornhill.

Temple Bar began with a circulation of about 30,000, and, as Sala put it, "held its own successfully as it grew in months and years." The staff and the list of contributors in that early period were never to include any figures of permanent importance, with the possible exception of Anthony Trollope, but they were all skillful journalists who understood popular taste and fed it the desired mixture of morality, sentimentality, and social consciousness. Sala's second-incommand was Edmund Yates, who eventually succeeded to the editorship in 1863 , and other regular assistants were John Oxenford, Blanchard Jerrold, T. H. Sotheby, and Robert Buchanan, who was to go on to write the famous attack on the pre-Raphaelites, "The Fleshly School of Poetry," in the Contemporary Review (I87I). Numbered among the frequent contributors of fiction were Mrs. Henry Wood, whose East Lynne surely remains in the popular 
imagination as symbolic of a large area of Victorianism, and Mary Elizabeth Braddon, who wrote in her long life eighty novels, almost all of them ringing commercial successes. The poets were relatively undistinguished. Such a minor figure as Alfred Austin, who was to become Poet Laureate (practically by default) during the period I 896-1913, looms largest among a group of artistic pygmies.

Sala's editorship continued until I 863, when Edmund Yates succeeded him. Sala had for some months been at a loss for time, being occupied in literally a dozen activities: he was contributing regularly to the Daily Telegraph and to the Illustrated London News, was writing a novel, was an active member of the Reform Club, belonged to the Restoration Committee of the Chapter House of Westminster Abbey, etc. Furthermore, he was never especially popular among his co-workers. For example, Arnold Bennett remarks in his Journal, in an entry for 2 I October I 897, of meeting a man who "told how G. A. Sala had got him to work for six months without paying a penny." His literary ability was also frequently under fire, especially from the critics of the Saturday Review. He was certainly no better or no worse than a score of other hack writers, but an ineffable something in his style seemed to irritate a good many readers; perhaps it was, as he admitted in his Life and Adventures, his own "turgid, inflated, and bombastic manner."

The transfer of the command of Temple Bar from Sala to Yates had several noteworthy aspects. The ostensible reason for Sala's relinquishment of the editorship was his departure for America in November I 863 to act as correspondent for the Daily Telegraph in reporting the Civil War, but as early as August I86I, John Maxwell had offered Anthony Trollope $\mathfrak{E}_{\mathrm{I}} 000$ a year to become editor, if you will undertake to supply a novel and fill the position that Mr. Sala now occupies.

All the real work of editorship will be performed-as heretofore-by $\mathrm{Mr}$. Edmund Yates, who would act with you as sub-editor.

It is curious to compare this apparently genuine picture of Yates doing "all the real work of editorship" with Sala's somewhat pompous reference in his autobiography to "Edmund Yates, whom I . . . fixed upon as my sub-editor." He never gives Yates any further real credit. 
In any case, Trollope refused Maxwell's strange offer, and Yates was at last rewarded for his labors by being appointed editor-inchief. He continued in this capacity until the summer of $\mathrm{r} 866$. During this period Temple Bar continued to grow in popularity and esteem. Indeed, its popularity was such that George Bentley, who shared with his father the operation of the great publishing house of that name, recognized that it was exactly the tonic needed to revive the firm's vitality. Bentley thereupon purchased Temple Bar, assumed its publication, and superseded Yates as editor, incorporating in the change a merger of Temple Bar with the relatively unsuccessful house organ Bentley's Miscellany.

The union was a happy one. Bentley continued as editor for almost thirty years, until his death in I 895. During his regime Temple Bar prospered, perhaps in part because it now had a crest marked "Fide et Fiducia" and because its title-page indicated that the Bentleys were "Publishers in Ordinary to Her Majesty the Queen"; but most probably the magazine's success was due to Bentley's shrewd editorial sense and his general artistic sensitivity. His contributors at various times included Trollope, Robert Louis Stevenson, Edmund Gosse, George Gissing, Mark Twain, Hans Christian Andersen, Turgenieff, A. Conan Doyle, Wilkie Collins, Bret Harte, Austin Dobson and the fabulous Marie Corelli.

When Bentley died in I 895, the entire holdings of his firm were acquired by the Macmillan Company, which continued to issue Temple Bar until its publication was suspended in 1906. Possibly Bentley took the heart of the magazine with him in his passing, for it was never the same afterwards; when Victoria died in I90I, Temple Bar fell into a deep decline and survived for only five undistinguished years. Actually, of course, the death of an editor and of a monarch were only symptoms of the motion of time; but the time had fled when Temple Bar was suited to an honored place on the solid mahogany table in the center of a solid middle-class parlor.

As in the analysis of any life-cycle, to understand the death of Temple Bar we must go back to its birth and its time of vigor. Such a study has been begun by the present writer at Rutgers University. Although thus far the area of close research has extended only through the decade of the I860's, it is already apparent that the success of the magazine was due to its appeal to the great upper- 
middle-class-not to the shopkeepers and tradespeople, but to the resolute householders who had lately begun to acquire wealth and education and servants, who read Tennyson and Dickens and thought much of the state of their souls (gravely, to be sure, without Wesleyan enthusiasm), and who considered the royal family quite the finest example of blended romance, duty, strength, intellect, and pragmatical spirituality that had ever blessed the civilized world.

The magazine under Sala acquired the format it was in essence to retain throughout its life. Each issue included two serial novels, one or two short stories, two or three sentimental poems, one article of literary appreciation or criticism of some current work, and a scattering of three or four articles on items of popular interest. Threading together these mixed contents were filaments of thought and conviction common to the average Temple Bar reader: fictional wives had to emulate Patient Griselda while noble heroes stood fast against a deluge of adversity; always religious sympathies leaned toward a Low Church or Broad Church bias, with an implied when not specific scorn of Catholics, Jews, Revivalists, and especially of advocates of Puseyism; the revelations of Darwin and the New Science were painfully squared with the tenets of Orthodoxy; and there ever abided the faith that literature of genuine merit had moral import and was written by men of great soul. The upper middle-class had found a voice that would utter comfortable truths without being uncomfortably intellectual.

The main figures who move in the pages of Temple Bar were quite an ideal race of heroines and heroes. The fictional ladies fall into two main groups: the beautiful, modest, long-suffering gentlewoman who is quiet and retiring, and the beautiful, modest, long-suffering gentlewoman who is queenly and social. The former is typified by Margaret Atherton of For Better, for Worse, with her "soft violet eyes and colorless cheeks, - the bands of her glossy brown hair drawn back from her broad, white, and rather low forehead, and twisted simply round her small classical head." Set over against this shy, ethereal sort was the heroine of the novelette Lady Laetitia's Lilliput Hand, who was "tall, and gracefully formed; she had the neatest ancle [sic] and most bewitching little foot in the world. . . Her bust, from the head downwards, was superb. Her eyes were resplendently dark, flashing liquid fire; her teeth were faultless ivory, 
and her lips were rosebuds." It may be observed from the foregoing description that Temple Bar heroines, despite a certain measure of Victorian propriety, at least had ancles and busts, unlike the virtually disembodied ladies who appeared in many other periodicals.

It would be a mistake to assume that Temple Bar was focussed solely on feminine interests, for a good part of its contents was devoted to industry and military affairs and such generally masculine areas of activity, but the bulk of its moral essays was devoted to the proper formation of womanly character. In March I86I the anonymous author of a series of brief biographies of virtuous ladies entitled "Daughters of Eve" was writing, "Woman's mission is first and principally to be a woman, and ... if she be simply and truly this, whatever else is the purport of her creation will follow easily and naturally thereupon." Much of this urging toward a sense of "mission" was of course due to the newly risen and highly vexing problem of the "Woman's Question." As early as its fifth issue (April I 86I) Temple Bar had taken its stand in an article by one of its lady authors: "The very name of the Woman's question has not yet ceased entirely to provoke a feeling of ridicule or weariness. ... I wish that we women had not been the originators of such feelings by our follies, our discontents, our pretensions to 'rights' and 'privileges' entirely unsuited to our physical and mental idiosyncracies." Still, Temple Bar was not entirely unsympathetic to the problems of young women who had to leave domestic security in times of family crisis. The question was, as a character in For Better, for Worse worriedly phrased it, "What employment can a woman undertake which is not open to some objections?" Pending an answer, female readers of Temple Bar were to be instructed by a whole series of moral essays, the general philosophy of which was summed up by "E.L.L." in "Loops and Parentheses": "The man to work, and the woman to love; the man to earn, and the woman to distribute; the man to protect, and the woman to cling,-ah! that is the ideal life."

In matters of religion Temple Bar of course stood squarely for piety and duty, if not for spirituality. The heroines of fiction were constantly speaking of God's love and the necessity of our cheerfully bearing our burdens in this vale of tears. Thus speaks the heroine of For Better, for Worse: "How hard it is to do one's duty steadily and unflinchingly! ... The reward, I suppose, will come in due 
time; but whether it does or not, it must be done." These exemplary ladies are matched by such gentlemen as the heroes of Aurora Floyd, of whom the author assures us, "Neither of them shall ever shock you by an ugly word or an unholy thought." A general godliness, then, was in the air, and respectable people everywhere made the assumption that religion belonged centrally in every life.

The "religion" the editors of Temple Bar had in mind was without doubt a fundamental Protestantism, the desired form of which was probably a kind of simple Low Church or Broad Church orthodoxy. Revivalism was surely in no way agreeable, being characterized as "scarcely respectable," with ministers who were "coarse, uneducated men, without manners and without feeling; mere ragamuffin ranters of the most vulgar stamp." Generally speaking, the editors of Temple Bar felt that they could refer without qualification to "that sombre melancholy and very unchristian hue which our lower religionists throw over the ... hopeful faith of Christ." With a few exceptions such as an occasional approval of the good works of the Sisters of Charity, Catholicism fared little better than Revivalism. John Donne is lauded not only for his poetry but because he has also done "some powerful argumentative writing . . . against Popery," and there are frequent references to the Jesuits and "their accomodating system of morality," etc. Judaism as a religion is hardly treated at all, but racially it is handled with utmost contempt. "No Jew could ever look like a gentleman," writes Sala in the sixth of his series of essays, "Breakfast in Bed." In distinction from Catholicism or Judaism, the High Church and Puseyism are usually considered a great and somehow effeminate joke, as in the satiric description of the young cleric "the Rev. Aureole Genuflex," with a "clear muslin band like a dog's collar round his neck," who preached against waltzing because he himself "could not dance from his habit of wearing peas in his shoes." At his throat, it should be added, he wore "a relic,- - petrified bit of cough-lozenge, supposed to have been bitten by St. Augustine.”

The probable certainty of one's view of religion was surely not matched by the troubled popular view of science in the I 860 's. To be sure, it was still possible in that decade for one to be excited to a naive wonder by the works of machines and to feel that the world was verging on the limit of technological progress. In I86r, for 
example, "J.S.," in "The Metamorphoses of Matter," was writing confidently that "the elementary bodies of terrestrial creation, and probably of the entire universe, are no more than about 66."

But this was a matter of small consequence, in the judgment of the public, in comparison to the staggering theories of Darwinism. The present-day student can gain a full realization of the impact of The Origin of Species only by reading some part of the torrent of literature that followed hard upon it. Now it must not be supposed that Temple Bar ever delved very deeply into the philosophy or practical theory of Darwinism, for its readers could hardly have borne such sinewy fare. However, it did indeed reflect the widespread awe and concern with which the New Science was regarded. One author, using the pseudonym "Clifton," reported in "The Recollections of a Geologist" in I 862:

I can remember the time when Geology was believed to be a dangerous study, and was spoken of by intelligent people with a disrespect bordering on contempt. It is now fashionable, and in every society you meet with men and women who talk about formations and fossils as if they had spent their lives in exploring the one and collecting the other. They tell you which theory is orthodox and which heretical.

It was the difficulty of sorting the orthodox theory from the heretical that disturbed most readers. An understandable vexation is expressed by Mortimer Collins in "Other Worlds," a poem dealing with the possibility of life on other planets:

\section{Does a mighty ocean roar and break}

On dark rocks and sandy shores fantastic?

Have they any Darwins there to make

Theories elastic?

The editors of Temple Bar never formulated a specific policy regarding Darwinism, but treated it in point of fact as a network of "theories elastic," printing articles both in support and opposition. In the sympathetic camp was the author of "The Pre-Adamite World," who wrote calmly that "the general tendency of discovery in modern times has been to throw great doubt on the correctness of the admitted chronologies," but who also pointed out that "a few years of geological progress have also served to adapt the minds of most readers for such considerations." Vigorous contradiction was provided in such articles as "The Battle of the Ethnologists," which 
maintained that the new "theories, if sustained, must set aside the inspired Word, or force us to give it new interpretations, if it be possible by any new interpretation to reconcile it with the demands of the new philosophy." The only possible explanation for the factual evidence sustaining the new theories, wrote this distressed author, would be "a miracle. ... And a miracle is something beyond our power to explain or scientifically investigate." One is reminded, in viewing this skirmish across the years, of Edmund Gosse's recollection in Father and Son of teachers "who held that God had scattered fossils about the world as a test of faith."

Just as Temple Bar was fundamentally superficial in its treatment of science, it never truly came to grips with the literary problems of the day. Its criticism is by no means penetrating. An analysis of references in the I 860 's, on a purely statistical basis, shows that Dickens is quite definitely the leader, with situations from David Copperfield, Oliver Twist, and Dombey and Son most often cited. For example, the sentimental heroine of The Doctor's Wife, a serialnovel of $\mathrm{I} 865$, watching her sick husband, thinks of "all the deaths in her favourite books: of Paul Dombey, fading slowly, day by day, with the golden water rippling on the wall; of David Copperfield, sitting weeping in the dusk; and Agnes, with her holy face and quiet uplifted hand." We may also note Winter-light ( I 862), a short story whose plot is cribbed almost directly from $A$ Christmas Carol, a Scrooge-type miser repenting of his avarice after a supernatural visitation and then giving money and good cheer to a deserving nephew.

The Romantic impulse which was still strong in Victorianism in that decade is demonstrated in the fact that Byron was its second most popular figure. His moral status is seldom remarked-and then only with censure- but his works, notably Childe Harold, Don Juan, Manfred, Lara, and The Giaour, are frequently mentioned. However, Byron was rapidly giving place to Tennyson, who was "profoundly versed in the workings of the human heart," and who had "a noble imagination." The author of a criticism of Winthrop Mackworth Praed in 1862 wrote:

The poetry of the day is preëminently Tennysonian. . . Ordinary readers of poetry have no admiration to spare for any productions in which Mr. Tennyson's subtlety and exquisite grace of language are not imitated. . . . Never, 
perhaps, even in Shakespeare's or Byron's days, has an English poet been so readily acknowledged as first by all his contemporaries.

Behind the three leaders in frequency of mention in Temple Bar there appeared, in order, Thackeray, Scott, Coleridge, Shelley, Wordsworth, Carlyle, and Longfellow. Keats and Arnold are referred to only at rare intervals, as is Browning, "the kernel of whose dry diction you find so sweet and savoury, after you have spent hours in getting at it." Mrs. Browning, too, is seldom mentioned, but her status in comparison with others of her sex is beyond measure. "A.A." (probably Alfred Austin) in a narrative, "At Florence," calls her "the greatest poetess, and, therefore, the greatest woman, that ever lived." Jane Austen, on the other hand, is unwillingly conceded by Buchanan to be an "artist," in his essay "Society's Looking Glass," but he goes on to say that she "was without imagination," and "full of the spirit of English parochialism." Generally speaking, it was supposed with approval that Romanticism and Religion had fused to form an ideal contemporary literature.

There were of course exceptions to the usual run of sentiments quoted thus far. It is so tempting to generalize freely about the midVictorians that one must in conscience point out such examples of chafing against the bit as an article of 1864 entitled "Manners to Mend," in which Sala grumbled at the growing emphasis on gentility and complained that it was debatable "whether the cause of national virtue and morality has benefited by the undeniable decorum and decency which have of late made themselves apparent in public manners. Is hypocrisy preferable to open and undisguised vice?" In a subsequent passage he reluctantly answered, "I think the verdict must be given in favor of judicious simulation." Mary Elizabeth Braddon in her novel The Doctor's Wife in the same year scolded her readers, "Nowadays the young people are older than their seniors." No longer did they indulge in such jolly pranks as "to set barrels of wine running in the Haymarket," she complained, "but in place of all this foolish riot and confusion a mortal coldness of soul seems to have come down upon the youth of our nation, a deadly languor and stagnation of spirit." As if such thrusts against polish and amenity were not enough, Temple Bar readers also had to endure the occasional accusation that the English were not at all 
properly maintaining the familial sanctity of the home. "E.L.L." wrote sharply in 1862 , "We English, insular and isolated, close the street-door fast, and call that emphatically 'home' which is only a carcase of four walls subdivided into cells. His house is 'home' to an Englishman, and sometimes all the home he has, the family counting for little or nothing."

There were times, too, when Temple Bar authors were almost cynical in their treatment of situational clichés in their novels. Mary Elizabeth Braddon, for example, had little patience with those murmured revelations of the death-bed that so often unravelled tangled plots. She wrote in Aurora Floyd, "I do not quite believe that people often make the pretty, sentimental, consecutive confessions under the influence of fever which are so freely attributed to them by the writers of romances." While Miss Braddon was sniping away at the literary conventions, several authors like "J.S." in "The Metamorphoses of Matter" were straying far from ideal gentility and must surely have shocked more than a few maidenly hearts in writing of such matters as bodily decay after death, "that festering wreck of poisonous corruption. Your flesh ... will have fretted into poisonous compounds, the veriest breath of which bursting free, as someday it must, will speed about pestilence-breeding." One might well ask what had happened to supposed Victorian "propriety" in passages such as this.

For in such a question lies the intrinsic fascination of Temple Bar. The magazine was in most ways a clear and forceful expression of upper-middle-class Victorianism, self-conscious and pompous and sober and striving confidently upward in an unending, expanding spiral of progress. But underneath this sometimes turgid stream of the sentimental and sanctimonious there glints an occasional flash of the rebellious - the doubt that all virgins of high degree are frail of heart, and the Swiftian obsession with the cloacal that is shown in one brief and frightening moment. The present study of Temple $B a r$ has not progressed sufficiently to have formed a clear statement of this corner of the Victorian paradox; but it has certainly progressed sufficiently to indicate that a close analysis of its literature can bring a new and very human dimension to the shadow-images of the men and women of that by-gone age. 